\title{
An Experimental Research on Partial Replacement of Coarse Aggregate with Recycled Aggregate And Fine Aggregate with Granite Powder
}

\author{
Ponnana Ramprasad, Allu Manikanta
}

\begin{abstract}
Now a days increase in population increases the demand of concrete for construction purpose and Aggregates are the important constituents in concrete.Re-use of demoliation waste avoids the problem of waste disposal and is also helpful in reducing the gap between demand and supply of fresh aggregates. This research deals with partial replacement of natural coarse aggregates (NCA) with recycled coarse aggregates (RCA) of age group 30 years and 35 years in different proportions like $20 \%, 30 \%, 40 \%$. For this, M20 grade of concrete is adopted. Curing of specimens were done for 7days and 28 days to attain the maximum strengths. Partial replacement of fine aggregate with Granite powder at 5\%, 10\%, $15 \%$ were done to reduce the waste percentage as well to gain more strength. After casting the specimens of RCA with Granite powder replacement, curing was done and the specimens were tested for compressive and tensile strengths.

Obtained results of compressive and tensile strengths of RCA concrete mix were compared with conventional concrete. In this direction, an experimental investigation of compressive and tensile strength was undertaken to use RCA as a partial replacement in concrete. It was observed that the concrete with recycled aggregates of 30years and 35years age group achieved maximum compressive strength of $29.03 \mathrm{~N} / \mathrm{mm}^{2}, 28.96$ $\mathrm{N} / \mathrm{mm}^{2}$ and tensile strength of $11.91 \mathrm{~N} / \mathrm{mm}^{2}, 10.34 \mathrm{~N} / \mathrm{mm}^{2}$ were obtained at 40\% replacement of $R C A$ respectively. It is found that the compressive strength and Split tensile strength of RAC with copper slag was increased $8.20 \%$ and $2.90 \%$ when compared with the RAC.
\end{abstract}

Index Terms: compressive strength, granite powder, recycled coarse aggregate

\section{INTRODUCTION}

Nominal concrete is made by mixing cement, fine aggregate, coarse aggregate and water. The worldwide consumption of natural coarse aggregate in mortar/concrete production is very high and several developing countries have faced some problems in the supply of natural coarse aggregate. In order to reach increasing needs of infrastructural development in present days researchers has done experimental study on utility of recycled coarse aggregates is taken as partial replacement of coarse total and stone powder is taken as fractional swap for fine total so as to diminish utilization of waterway sand and to utilize mechanical waste so as to lessen the development of waste in dumpy yards. Be that as it may, three viewpoints are picking up accentuation in the utilization of this solid. The first is the sturdiness angle. The significance of strength is

Revised Manuscript Received on July 18, 2019.

Ponnana Ramprasad, M.Tech.,(Ph.D) , Assistant Proffesor, Department of Civil Engineering, Aditya Institution of Technology And Management, K.Kotturu, India

Allu Manikanta, M.Tech Department of Civil Engineering, Aditya Institution of Technology And Management, K.Kotturu, India. very much done in the changed code practice on cement IS456-2000. The subsequent perspective is economy in development by cost decrease in reusing materials and modern misuse of copper slag. The third viewpoint identified with preservation and natural assurance. The most significant issue that structures the premise of this undertaking is that the measure of development and destruction squander in landfill locales and regions side streets is relied upon to increment sooner rather than later at worldwide levels. The higher porosity of the RAC is because of higher substance of followed mortar in charge of its low obstruction towards mechanical and concoction activities. Because of the nearness of miniaturized scale breaks and leftover bond glue clung to the external layer of reused solid flotsam and jetsam, the expanded porosity of totals for the most part brings about extensively most elevated water ingestion for the synthetic responses and, therefore, the real water-concrete proportion.

\section{A. Objective}

The main objective of this study is to make M20 grade of concrete with $20 \%, 30 \%, 40 \%$ RCA of 30\& 35 years age groups as coarse aggregate and 5\%, 10\%, 15\% Granite powder and study its mechanical properties.

\section{LITERATURE REVIEW}

1.Shehdeh Ghannam, Husam Najm, Rosa Vasconez who made the studies on replacement of sand with fine aggregate for the structural concrete production. This was published on 8 November 2015. A comparative analysis of experimental results of properties of fresh and hardened concrete with different replacement of sand with granite powder is presented in this paper.In this the fine aggregate replaced as $0 \%, 5 \%, 10 \%, 15 \%, 20 \%$ and $25 \%$ with granite powder. But from his results he suggested that the quality of concrete and strength parameters of concrete with granite powder depends upon the quality of granite powder produced. It is also mentioned that by following proper mix design only we can get better results in accordance with conventional concrete. The reasons for lower quality of concrete with granite powder is the adhered cement motor to the surface of aggregate and increased water absorption.

2.Mirjana Malesev, who made the investigations on Recycled concrete as total for basic solid generation. This was distributed on 30 April 2010. A similar examination of the exploratory consequences of properties of new and 


\section{AN EXPERIMENTAL RESEARCH ON PARTIAL REPLACEMENT OF COARSE AGGREGATE WITH RECYCLED AGGREGATE AND FINE AGGREGATE WITH GRANITE POWDER}

solidified cement with various supplanting proportions of characteristic totals with reused coarse totals is displayed in this paper. In this the coarse total is supplanted as half and $100 \%$ with RCA. In any case, from his outcomes he proposed that the nature of cement and quality parameter of cement with RCA relies on the nature of RCA created. It is likewise referenced that by following legitimate blend structure no one but we can show signs of improvement brings about understanding with traditional cement. The purposes behind lower nature of cement with RCA are the clung concrete mortar to the outside of total and expanded water retention. By taking appropriate measures and structuring a blend plan we can get best outcomes for RCA.

3. Hardik Gandhi, Dr. Dharshana Bhatt, Chetnader Vyas, there is a basic lack of virgin totals and henceforth the accessibility of wrecked cement for use as reused solid total is expanding. Utilizing the waste concrete as RCA preserves virgin totals, lessens the effect on landfills, diminishes the vitality utilization and can give cost reserve funds. Reused totals are included squashed, reviewed, inorganic particles handled from the materials that have been utilized in development and destruction trash. Reused totals for application in high quality auxiliary solid, which gives a superior comprehension on the properties of cement with reused total as an elective material. In the present investigation reused coarse total have been utilized to supplant virgin coarse total. The trial results demonstrates that the compressive quality of cement made of normal coarse total and reused coarse total is around the equivalent. Along these lines, it tends to be utilized in cement with fractional substitution of common total.

\section{METHODOLOGY}

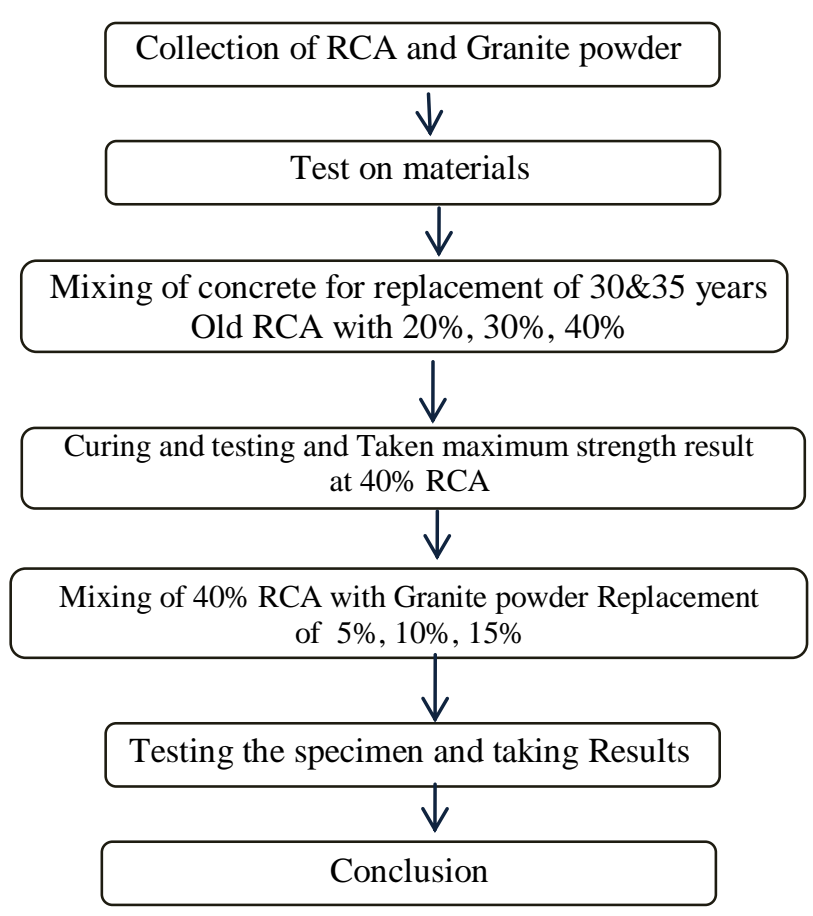

IV. MATERIALS USED

\section{A. Cement}

Ordinary Portland cement of grade 43, conforming to IS 8112-2013 was used. Physical properties of cement used are reported in Table 1. Method of tests were referred with IS 4031-1988 Part 2,3,5,8 and IS1727 - 1967.

Table 1 Properties of Cement

\begin{tabular}{|c|c|c|c|}
\hline S.No & $\begin{array}{c}\text { Test } \\
\text { particulates }\end{array}$ & Results & Remarks \\
\hline 1 & $\begin{array}{c}\text { Specific } \\
\text { gravity of } \\
\text { cement }\end{array}$ & 2.89 & $\begin{array}{c}2-3 \text { is suitable } \\
\text { as per IS } \\
\text { CODE }\end{array}$ \\
\hline 2 & $\begin{array}{c}\text { Normal } \\
\text { Consistency of } \\
\text { Cement }\end{array}$ & $34 \%$ & $25 \%-38 \%$ \\
\hline 3 & $\begin{array}{c}\text { Initial setting } \\
\text { time }\end{array}$ & 41 mints & $\begin{array}{c}\text { Should be } \\
\text { more than } 30 \\
\text { mints }\end{array}$ \\
\hline 4 & $\begin{array}{c}\text { Final setting } \\
\text { time }\end{array}$ & 572 mints & $\begin{array}{c}\text { Should not be } \\
\text { more than } 600 \\
\text { mints }\end{array}$ \\
\hline 5 & $\begin{array}{c}\text { Fineness of } \\
\text { cement }\end{array}$ & $4 \%$ & \\
\hline
\end{tabular}

\section{B. Natural Coarse Aggregate and RCA}

Natural coarse aggregate(NCA) was used from nearby quarries and recycled coarse aggregate(RCA) of 30 years age group and 35 years age group was imported and chipped as coarse aggregate. These were tested in in laboratory, the test results were as follows.

Table 2 Properties of NCA \& RCA

\begin{tabular}{|c|c|c|c|c|}
\hline S.No & Property & $\begin{array}{c}\text { Obtaine } \\
\mathrm{d} \text { results } \\
\text { for } \\
\text { NCA }\end{array}$ & $\begin{array}{c}\text { Obtaine } \\
\text { d results } \\
\text { for 30 } \\
\text { years } \\
\text { age }\end{array}$ & $\begin{array}{c}\text { Obtained } \\
\text { results for } \\
35 \text { years age }\end{array}$ \\
\hline 1. & $\begin{array}{c}\text { Impact } \\
\text { test }\end{array}$ & $26.47 \%$ & $18.18 \%$ & $15.37 \%$ \\
\hline 2. & $\begin{array}{c}\text { Crushing } \\
\text { test }\end{array}$ & $26.60 \%$ & $16.93 \%$ & $17.35 \%$ \\
\hline 3. & $\begin{array}{c}\text { Specific } \\
\text { gravity }\end{array}$ & $26.40 \%$ & 2.34 & 2.13 \\
& $\begin{array}{c}\text { Los } \\
\text { angles } \\
\text { abrasion } \\
\text { test }\end{array}$ & 2.72 & 2.43 & 2.15 \\
\hline
\end{tabular}

C. Fine Aggregate

Most important constituent in the concrete to provide stability and work-ability. Fine aggregate of following physical properties were imported and tested in laboratory. 
Table 3 Properties of Fine Aggregate

\begin{tabular}{|c|c|c|c|c|c|}
\hline $\begin{array}{c}\text { S.N } \\
\text { o }\end{array}$ & $\begin{array}{c}\text { IS } \\
\text { e } \\
(\mathrm{mm} \\
)\end{array}$ & $\begin{array}{c}\text { Wt. } \\
\text { in Grams }\end{array}$ & $\begin{array}{c}\text { \% Wt. } \\
\text { Retaine } \\
\mathrm{d}\end{array}$ & $\begin{array}{c}\text { Cumulativ } \\
\text { e of Wt. } \\
\text { Retained }\end{array}$ & $\begin{array}{c}\% \text { of } \\
\text { Passin } \\
\mathrm{g}\end{array}$ \\
\hline 1 & 4.75 & 0 & 0 & 0 & 100 \\
\hline 2 & 2 & 147.925 & 9.87 & 9.86 & 90.14 \\
\hline 3 & 1 & 157.235 & 10.48 & 20.34 & 79.66 \\
\hline 4 & 0.6 & 350 & 23.33 & 43.67 & 56.33 \\
\hline 5 & 0.3 & 440 & 29.33 & 73 & 27 \\
\hline 6 & 0.15 & 360 & 24 & 97 & 3 \\
\hline 7 & 0.07 & 34.48 & 2.29 & 99.29 & 0.71 \\
\hline
\end{tabular}

\section{Granite Powder}

Rock powder is a waste material from the stone cleaning industry, is a promising material for use in cement like those of pozzolanic materials, for example, silica seethe, fly ash, Copper slag and others. These items can be utilized as a filler material (substituting sand) to diminish the void substance in cement.

Table 4 Properties of Granite Powder

\begin{tabular}{|l|l|l|l|l|l|}
\hline $\begin{array}{l}\text { S.N } \\
\text { o }\end{array}$ & $\begin{array}{l}\text { Is } \\
\text { Sieve } \\
(\mathrm{mm})\end{array}$ & $\begin{array}{l}\text { Weight } \\
\text { Retaine } \\
\mathrm{d}(\mathrm{G})\end{array}$ & $\begin{array}{l}\text { \% Wt. } \\
\text { Retaine } \\
\mathrm{d}\end{array}$ & $\begin{array}{l}\text { Cumulativ } \\
\text { e wt. } \\
\text { Retained }\end{array}$ & $\begin{array}{l}\% \text { of } \\
\text { Passing }\end{array}$ \\
\hline 1 & 4.75 & 0 & 0 & 0 & 100 \\
\hline 2 & 2.0 & 0.011 & 1.1 & 1.1 & 98.9 \\
\hline 3 & 1.0 & 0.081 & 8.1 & 9.2 & 90.8 \\
\hline 4 & 0.6 & 0.138 & 13.8 & 23 & 97.7 \\
\hline 5 & 0.3 & 0.056 & 5.6 & 28.6 & 71.4 \\
\hline 6 & 0.15 & 0.018 & 1.8 & 30.4 & 69.6 \\
\hline 7 & 0.075 & 0.88 & 8.8 & 40 & 60 \\
\hline
\end{tabular}

\section{TEST RESULTS}

Table:5 compressive strength with different replacement percentage of $\mathbf{3 0}$ years recycled aggregate

For concrete $20 \%, 30 \%, 40 \%$ and $100 \%$ replacement of NCA and RCA

\begin{tabular}{|c|c|c|c|c|}
\hline $\begin{array}{c}\text { CEMENT } \\
\text { REPLAC } \\
\text { EMENT }\end{array}$ & $\begin{array}{c}\% \text { OF } \\
\text { RCA }\end{array}$ & $\begin{array}{c}\% \text { OF } \\
\text { RFA }\end{array}$ & $\begin{array}{c}\text { AVG. } \\
\text { OF 7 } \\
\text { DAYS } \\
\text { Fck } \\
\left(\mathrm{N} / \mathrm{MM}^{2}\right)\end{array}$ & $\begin{array}{c}\text { AVG. OF } \\
28 \text { DAYS } \\
\text { Fck } \\
\left(\mathrm{N}^{2} / \mathrm{MM}^{2}\right)\end{array}$ \\
\hline $0 \%$ & $20 \%$ & $0 \%$ & 24.28 & 26.31 \\
\hline $0 \%$ & $30 \%$ & $0 \%$ & 25.21 & 28.75 \\
\hline $0 \%$ & $40 \%$ & $0 \%$ & 28.31 & 29.03 \\
\hline & $100 \%$ & $0 \%$ & 23.18 & 26.89 \\
\hline
\end{tabular}

Graph 1 compressive strength with different replacement percentage of 30 years recycled coarse aggregate

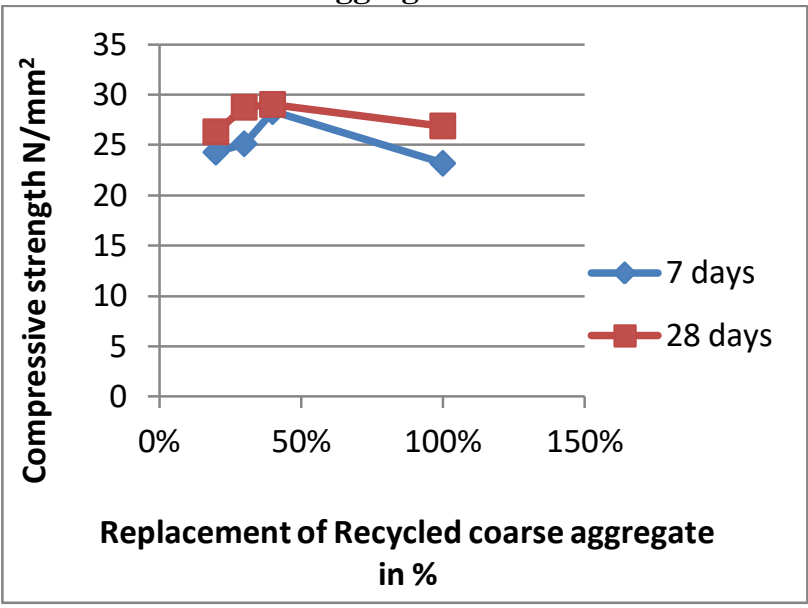

Description of results

1. From fig 4.5.1 the compressive strength of concrete is increased gradually from $20 \%$ to $40 \%$ and attained a maximum value at a replacement of $40 \%$ recycled aggregate in coarse aggregate and $0 \%$ replacement of fine aggregate while comparing with controlled specimen.

2. The compressive strength of concrete is decreased for $100 \%$ of replacement.

3. However compressive strength of concrete for the partial replacement of coarse aggregate with recycled aggregate at $40 \%$ obtained more compressive strength. So that replacement of coarse aggregate with recycled aggregate is finalized at $40 \%$ for their replacement.

Table-6 compressive strength with different replacement percentage of granite powder and 30 years recycled aggregate

For concrete $5 \%, 10 \%$ and $15 \%$ replacement of sand and granite powder

\begin{tabular}{|c|c|c|c|c|}
\hline $\begin{array}{c}\text { CEMEN } \\
\text { T } \\
\text { REPLAC } \\
\text { EMENT }\end{array}$ & $\begin{array}{c}\text { OF } \\
\text { RCA }\end{array}$ & $\begin{array}{c}\text { \% OF } \\
\text { GRANITE } \\
\text { POWDER } \\
\text { (RFA) }\end{array}$ & $\begin{array}{c}\text { AVG. Of } \\
\text { 7 DAYS } \\
\text { Fck } \\
\left(\text { NMM }^{2}\right)\end{array}$ & $\begin{array}{c}\text { AVG. OF } \\
\text { 28 DAYS } \\
\text { Fck } \\
\left(\text { N/MM }^{2}\right)\end{array}$ \\
\hline $0 \%$ & $40 \%$ & $5 \%$ & 26.87 & 29.58 \\
\hline $0 \%$ & $40 \%$ & $10 \%$ & 28.48 & 31.2 \\
\hline $0 \%$ & $40 \%$ & $15 \%$ & 29.7 & 32.08 \\
\hline
\end{tabular}



RECYCLED AGGREGATE AND FINE AGGREGATE WITH GRANITE POWDER

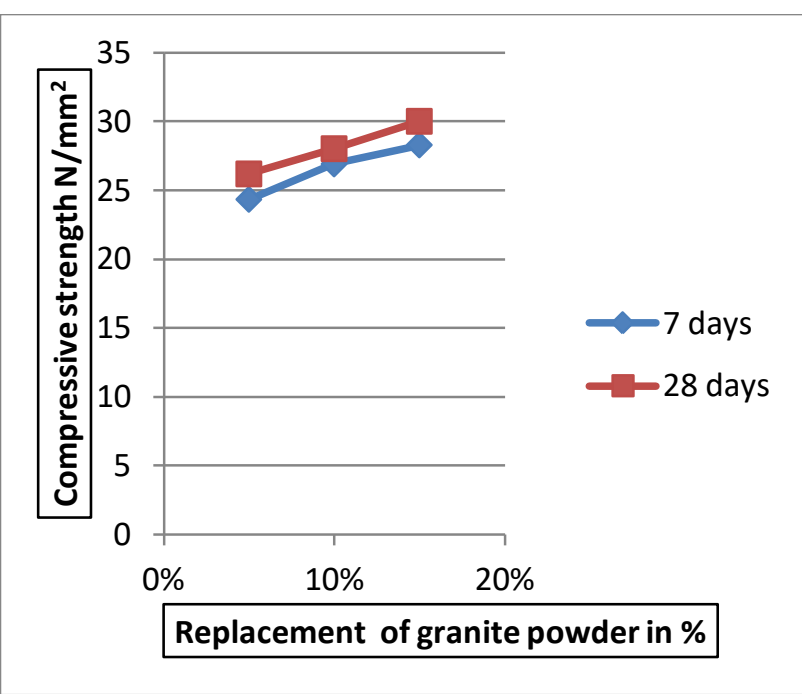

Graph-2 compressive strength with different replacement percentage of granite powder and 30 years recycled aggregate

Description of results:

1. From fig 4.5.2 the compressive strength of concrete is increased gradually from $5 \%$ to $15 \%$ and attained a maximum value at a replacement of $15 \%$ granite powder in fine aggregate and $40 \%$ replacement of 30 years recycled aggregate while comparing with controlled specimen.

2. However compressive strength of concrete for the partial replacement of fine aggregate with granite powder at $15 \%$ and partial replacement of coarse aggregate with 30 years recycled aggregate at $40 \%$ obtained more compressive strength.

Table-7 compressive strength with different replacement percentage of 35 years recycled aggregate

For concrete $20 \%, 30 \%, 40 \%$ and $100 \%$ replacement of NCA and RCA

\begin{tabular}{|c|c|c|c|c|}
\hline $\begin{array}{c}\text { CEMENT } \\
\text { REPLAC } \\
\text { EMENT }\end{array}$ & $\begin{array}{c}\text { OF } \\
\text { RCA }\end{array}$ & $\begin{array}{c}\text { \% OF } \\
\text { RFA }\end{array}$ & $\begin{array}{c}\text { AVG.OF } \\
\text { 7 DAYS } \\
\text { Fck } \\
\left.\text { (N/MM }^{2}\right)\end{array}$ & $\begin{array}{c}\text { AVG. } \\
\text { OF 28 } \\
\text { DAYS } \\
\text { Fck } \\
\left(\text { N/MM }^{2}\right)\end{array}$ \\
\hline $0 \%$ & $20 \%$ & $0 \%$ & 23.74 & 27.04 \\
\hline $0 \%$ & $30 \%$ & $0 \%$ & 24.53 & 27.44 \\
\hline $0 \%$ & $40 \%$ & $0 \%$ & 27.08 & 28.96 \\
\hline $0 \%$ & 100 & $0 \%$ & 22.30 & 25.13 \\
\hline
\end{tabular}

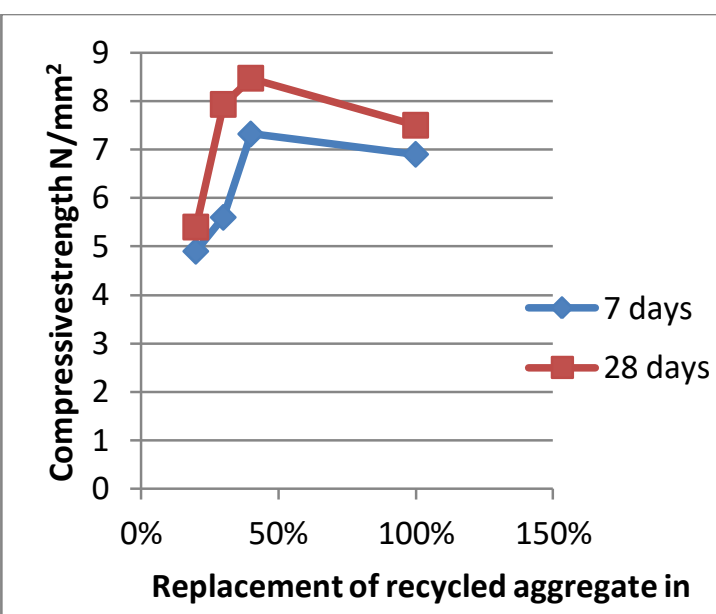

$\%$

Graph-3 compressive strength with different replacement percentage of 35 years recycled aggregate

\section{Description of results:}

1. From fig 4.5.3 the compressive strength of concrete is increased gradually from $20 \%$ to $40 \%$ and attained a maximum value at a replacement of $40 \%$ recycled aggregate in coarse aggregate and $0 \%$ replacement of fine aggregate while comparing with controlled specimen.

2. The compressive strength of concrete is decreased for $100 \%$ of replacement

3. However compressive strength of concrete for the partial replacement of coarse aggregate with recycled aggregate at $40 \%$ obtained more compressive strength. So that replacement of coarse aggregate with recycled aggregate is finalized at $40 \%$ for their replacement.

Table-8 compressive strength with different replacement percentage of granite powder and 35 years recycled aggregate

For concrete $5 \%, 10 \%$ and $15 \%$ replacement of sand and granite powder

\begin{tabular}{|c|c|c|c|c|}
\hline $\begin{array}{c}\text { CEMENT } \\
\text { REPLACEME } \\
\text { NT }\end{array}$ & $\begin{array}{c}\% \text { OF } \\
\text { RCA }\end{array}$ & $\begin{array}{c}\% \\
\text { OF } \\
\text { RFA }\end{array}$ & $\begin{array}{c}\text { AVERAG } \\
\text { E DAYS } \\
\text { Fck } \\
\left(\text { N/MM }^{2}\right)\end{array}$ & $\begin{array}{c}\text { AVG. OF } \\
\text { 28 DAYS } \\
\text { Fck } \\
\left(\text { N/MM }^{2}\right)\end{array}$ \\
\hline $0 \%$ & $40 \%$ & $5 \%$ & 24.34 & 26.19 \\
\hline $0 \%$ & $40 \%$ & $10 \%$ & 26.91 & 28.02 \\
\hline $0 \%$ & $40 \%$ & $15 \%$ & 28.29 & 30.01 \\
\hline
\end{tabular}


Graph-4 compressive strength with different replacement percentage of granite powder and 35 years recycled aggregate

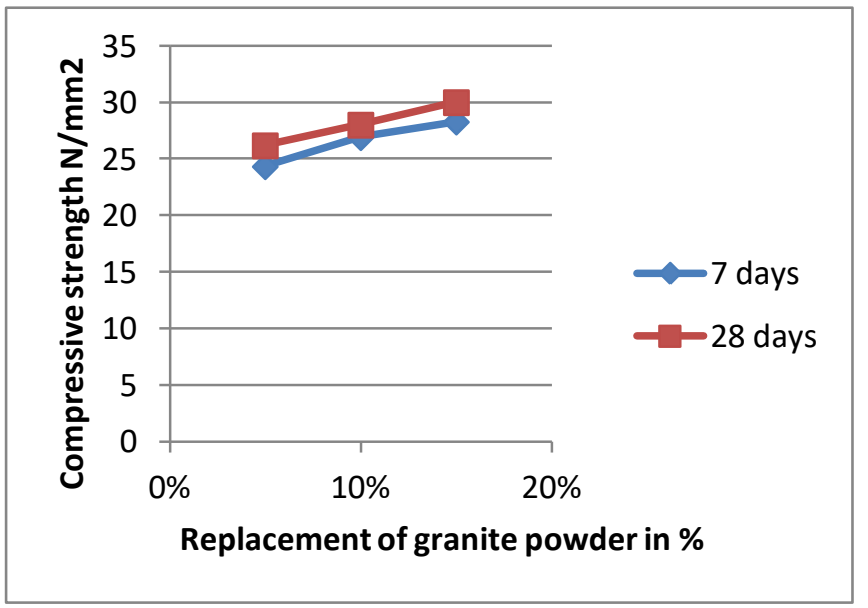

Description of results

1. From fig 4.5.4 the compressive strength of concrete is increased gradually from $5 \%$ to $15 \%$ and attained a maximum value at a replacement of $15 \%$ granite powder in fine aggregate and $40 \%$ replacement of 35 years recycled aggregate while comparing with controlled specimen.

2. However compressive strength of concrete for the partial replacement of fine aggregate with granite powder at $15 \%$ and partial replacement of coarse aggregate with recycled aggregate at $40 \%$ obtained more compressive strength.

\section{CONCLUSION}

From the experimental investigation on coarse aggregate partially replaced with RCA and fine aggregate was partially replaced with granite powder to improve the mechanical properties as follows.

The compressive strength and of concrete with recycled aggregate and concrete with granite powder as partial replacements are compared and observed that the strength of the concrete with recycled aggregate is slightly lesser than the granite powder replaced concrete.

1. The compressive strength increases with increasing percentage of granite powder up to $15 \%$ by weight of fine aggregate and recycled aggregate up to $40 \%$ by weight of coarse aggregate.

2. The split tensile strength increases with increasing percentage of granite powder up to $15 \%$ by weight of fine aggregate and recycled aggregate up to $40 \%$ by weight of coarse aggregate.

3. From the results of compressive strength, split tensile strength of 7,28 days curing $15 \%$ replacement of fine aggregate by granite powder and $40 \%$ replacement of coarse aggregate by recycled aggregate is the optimum percent of M20 grade concrete.

4. The following benefits can be obtained by using granite powder:

i. Cost reduction

ii. Utilization of waste material is possible in construction by using granite powder a partial replacement material for fine aggregate in concrete.

\section{SCOPE OF THE PROJECT}

Recycling of stone, aggregate, will be reduce the quarrying and mining for stones. The earth surface can be saved and ecological disturbances will be reduced.The ability of land for waste disposal will be increased To conserve the conventional natural aggregate for other important works.

\section{REFERENCES}

1. Mather, Bryant, "Laboratory tests of Portland slag cement" ACI journal, 54, no 3, September 1957, pp. 205232.

2. Fulton, F. S., "The properties of PSC Containing milled granulated blast furnace slag," monograph, Portland cement institute, Johannesburg, 1974, pp. 4-46.

3. Hogan, F.J. and meusel, J.W., 'The elevation of durability and strength development of a ground granulated blast-furnace slag', 457 cement, concrete, and aggregate 3 (1) (1981) 41-52.

4. KK Sagoe-crentsil, T Brown, AH Taylor "Performance of concrete made with commercially produced coarse recycled concrete aggregate" Cement and concrete research, 2001 - Elsevier.

5. PC Yong, DCL Teo "Utilization of recycled aggregate as coarse aggregate in concrete" journal of civil engineering and science. Performance of concrete made with commercially produced coarse recycled concrete aggregate.

6. Poon, CS and Chan D (2006) the use of recycled aggregate in concrete in Hong Kong. Journal of resource, conservation and recycling, 50 (2007).

7. SM Levy, P Helene "Durability of recycled aggregate concrete" cement and concrete research, 2004-Elsevier when this replacement was $20 \%$ or $50 \%$, mainly for the recycled coarse and fine aggregate.

8. V Corinaldesi "Mechanical and elastic behavior of concretes made of recycled concrete" construction and building materials, 2010-Elsevier.

9. A Gokce, S Nagataki, T Saeki, M Hisada "Freezing and thawing resistance of air entrained concrete incorporating recycled coarse aggregate" cement and concrete research, 2004-Elsevier.

10. A Katz "Properties of concrete made with recycled from partially hydrated old concrete" cement and concrete, 2003-Elsevier.

11. MB de Oliveira, E Vazquez "the influence of retained moisture in aggregate from recycling on the properties of new hardened concrete" waste management, 1996Elsevier.

12. G Fathifazi, AG Razaqpur, QB Isghor, A Abbas "Creep and drying shrinkage characteristics of concrete produced with coarse recycled concrete aggregate " cement and concrete, 2011-Elsevier.

13. V Corinaldesi, G Moriconi "Influence of minerals ad6ditions on the performance of $100 \%$ recycled aggregate concrete" construction and building materials, 2009-Elsevier. 


\section{AUTHORS PROFILE}

Ponnana ramprasad m.tech.,(ph.d) , assistant proffesor, Department of Civil Engineering, Aditya Institution of Technology And Management, K.Kotturu, INDIA.

Allu Manikanta,(M.Tech Department of Civil Engineering, Aditya Institution of Technology And Management, K.Kotturu, INDIA. 